\title{
Toxicological, Histological and Biochemical Effects of Lepidium sativum Seeds Extract on Galleria mellonella L. (Lepidoptera: Pyralidae) Larvae Extract
}

\author{
Rehab, M. El-Gendy \\ Pest Physiology Department, Plant Protection Research Institute, \\ Agricultural Research Center, Dokki, Giza, Egypt.
}

\begin{abstract}
The greater wax moth Galleria mellonella L. is a serious destructive pest of honeybee colonies in the beekeeping industry all over the world. The larvae feed on almost all of the honeybee products and have the ability to completely destroy the bee colony, especially the weakened ones. The toxicity and biochemical effect of garden cress, Lepidium sativum seeds methanolic extract as natural product against greater wax moth was evaluated under laboratory conditions. The defatted seeds $(250 \mathrm{~g})$ of garden cress were refluxed in $500 \mathrm{ml}$ methanol, filtered and then dried using a rotary evaporator. Results revealed that the toxic effect of the garden cress extract against $5^{\text {th }}$ instar larvae of G. mellonella was $1.15 \%,\left(\mathrm{LC}_{50}\right)$ after $24 \mathrm{~h}$. which induced more histopathological alterations on cuticle layers, fat bodies and muscle. A significant reduction in protein content, as well as high significant inhibition in $\alpha, \beta$ esterase and phenol oxidase activities were also recorded. On other hand, the extract induced an elevation in total lipid content and acid phosphatase activity. Furthermore, apoptotic DNA fragmentation was occurred at concentrations of 3, 2 and 1\%. GC-MS analysis illustrated the toxic effect of methanol extract of L. sativum seeds is related to a high ratio of phenolic, flavonoid and fatty acids constituents.

Keywords: Galleria mellonella, Lapidium sativum, DNA fragmentation, Integument histopathological, GC-
\end{abstract} MS analysis

\section{INTRODUCTION}

The greater wax moth, Galleria mellonella (Lepidoptera: Pyralidae) is widely distributed all over the world as one of the most serious pests in apiaries for honeybee colonies and stored bee wax. $G$. mellomella moth lays eggs in the wooden incisions of bee hives far onward from honeybee workers (Fathy et al., 2017). The larval stage is only the feeding stage through its life cycle, feeds on most of honey bee products as pollen, honey, beeswax and brood induced tunnels lined with silken material causing huge destroy of honeycombs and turned the wax combs into a pile of debris. Moreover, adult and larvae may also be implicated in the spread of microbial diseases as foulbrood disease (Owayss and Abd-Elgayed, 2007). The progress in larval development leads to the complete consumption of the honeycombs within a week of habitation (Hosamani et al., 2017), which results in severe economic loss to the beekeeping industry all over the world (Ellis et al., 2013).

The extensive use of fumigants and other synthetic pesticides that are used in G. mellonella control programs caused severe problems not only increase its resistance toward used pesticides but also effect negatively on the environment and human health. Nowadays, the uses of natural products based on plants are considering a promising, safe, sustainable alternative to chemical pesticides (Koul et al., 2008). Recently, many plants subjected to further investigation, and their secondary metabolites have been formulated as botanical pesticides that can be used in pest management programs (El-Gendy and El-Shafiey, 2018).

Garden cress, Lepidium sativum L. (Brassicaceae), is an annual edible herb that is widely distributed in many regions as North America, West Asia, Europe and Egypt, known in Egyptian local markets as Hab ElRashad (Chatoui et al., 2016). L. sativum and its extract have many medicinal properties and have been studied largely and used for many years as a therapy for several human diseases (Shail, 2016). The seeds of $L$. sativum contain several essential fatty oils, protein, carbohydrates, vitamins, and flavonoids (Yadav et al., 2010). Few in vitro studies explained the influence of L. sativum seeds methanolic extract on DNA damage and the apoptosis of cancer cells (Basaiyye et al., 2019).

The main goal of this research is to evaluate the efficacy of the methanolic extract of $L$. sativum seeds as a natural product against larval stage of $G$. mellonela and examine its impacts on the genomic DNA, integument histology, and biochemical alterations.

\section{MATERIALS AND METHODS}

\section{Insect rearing}

G. mellonella eggs were collected from the infested bee wax comb and maintained in jars covered with a muslin cloth for hatching. The hatched larvae were fed with natural wax; both eggs and larvae were incubated at $30 \pm 2^{\circ} \mathrm{C}$ and $78 \%$ RH (Mohamed et al., 2014).

\section{Preparation of methanolic extract of Lepidium sativum seeds}

The seeds of garden cress were purchased from a local market. L. sativum seeds powder $(250 \mathrm{~g})$ resulted from seeds fixed oil extracted with petroleum ether (defatted seeds) were refluxed in $500 \mathrm{ml}$ methanol in a glass jar for 5 days at room temperature. The filtered was concentrated to dryness in a rotary evaporator (RV 05 Janke \& Kunkel, IKA-WERK, German) and kept at $4{ }^{\circ} \mathrm{C}$ till use. 
Identification of the bioactive compounds of methanolic extract of Lepidium sativum seeds

\section{GC-MS analysis}

The GC/MS analysis was performed using a Thermo-Scientific, Trace GC Ultra/ISQ Single Quadrupole MS, TG-5MS fused silica capillary column (30m, $0.251 \mathrm{~mm}, 0.1 \mathrm{~mm}$ film thickness). GC/MS detected by the electron ionization system with ionization energy of 70ev. The carrier gas is helium at a constant flow rate $(1 \mathrm{~mL} / \mathrm{min})$. MS transfer line temperature in the injector was set at $280{ }^{\circ} \mathrm{C}$. The temperature of the oven start with $50{ }^{\circ} \mathrm{C}$ as initial temperature (hold $2 \mathrm{~min}$ ) to $150{ }^{\circ} \mathrm{C}$ at an increasing rate of $7{ }^{\circ} \mathrm{C} / \mathrm{min}$, then to 270 at an increasing rate $5{ }^{\circ} \mathrm{C} / \mathrm{min}$ (hold $2 \mathrm{~min}$ ) then to 310 as a final temperature at an increasing rate of $3.5{ }^{\circ} \mathrm{C} / \mathrm{min}$ (hold $10 \mathrm{~min}$ ). The identified components were exhibited using a percent relative peak area, retention time, and mass spectra based on the database of the National Institute of Standard and Technology (NIST) of the GC/MS system.

\section{Toxicity Bioassay}

Stock solution of the methanolic extract of $L$. sativum seeds was prepared at $(0.1 \mathrm{~g}$ : $10 \mathrm{ml}$ solvent $)$. Serial concentrations of $6,4,3,2,1,0.5$ and $0.25 \%$ were prepared in $10 \mathrm{ml}$ methanol to evaluate its toxicity on the fifth instar larvae of G. mellonella. Ten larvae were immersed in $5 \mathrm{ml}$ of each concentration. However, the positive control group was immersed in $5 \mathrm{ml}$ methanol and the negative control group was dipped in $5 \mathrm{ml}$ distilled water for $10 \mathrm{sec}$. The treated insects were then transferred into $90 \mathrm{~mm}$ Petri dish lined with filter paper tightly closed with sticky tape without food. Five replicates were prepared for each concentration and control groups (Hussien et al., 2021). The mortality rate was recorded every $24 \mathrm{hrs}$ post treatment.

\section{Histopathological studies}

Live $5^{\text {th }}$ instar larvae were taken after 24 posttreatment with $\mathrm{LC}_{50}$ of $L$. sativum methanolic extract. The samples of larvae in control and treatment groups were etherized after cutting their heads and the end of their abdomens. Neutral formaldehyde was used as a fixation solution for 12-24 hours. Embedded larval tissue in blocks were prepared after samples subjected to washing, dehydration, clearing, finally soft paraffin and hard paraffin treatments, respectively. Thereafter, samples were vacuumed in hard paraffin serial sections and taken from the blocks in 6-7 microns by microtome and stained with a combination of Hematoxylin-Eosin. Thin sections were visualized under the light microscope (NLCD-120, PN 14003, LAMP S-LED W1, China).

\section{DNA fragmentation assay}

The DNA damage of $5^{\text {th }}$ instar larvae was detected after 24-hour of treatments with $3 \%, 2 \%, 1 \%\left(\mathrm{LC}_{50}\right)$ of L. sativum seed-methanolic extract. The larvae treated with methanol as positive control; however, healthy one was used as negative control. DNA damage was examined by DNA fragmentation assay (Bortner et al.,
1995). DNA extraction was performed as described by (Phillips and Simon, 1995). The extracted DNA was run at a low voltage ( 50.0 volts) which improves the resolution of DNA fragments using $1.2 \%$ agarose gel and was run on electrophoresis (NANOPAC-300, Cleaver Scientific Ltd, UK). Then agarose gel was stained with ethidium bromide and visualized by UV transilluminator. An image of samples was analyzed using Gel Analyzer 19.1; an image analysis software (Lazar, 2010).

\section{Biochemical assay}

The survived $G$. mellonella larvae as a hole bodies treated with $\mathrm{LC}_{50}(1.15 \%)$ of $L$. sativum methanolic seeds extract were weighted and frozen after $24 \mathrm{~h}$. The frozen samples were homogenized in $1 \mathrm{ml}$ of distilled water using chilled glass Teflon homogenizer (MPW-309 Mechanic-Preczyina, Poland) and centrifuged (Hettich, Germany) at $6.000 \mathrm{~g}$ for $10 \mathrm{~min}$ at $5^{\circ} \mathrm{C}$. The supernatant of each group was used to estimation of enzyme activities and total soluble protein amount. Meanwhile, the homogenates were used to measure the total lipid content (El-Gendy and El Shafeiy (2018).

\section{Total soluble protein (TSP)}

Total soluble protein was estimated calorimetrically following the method described by Gornall et al. (1949). A violet purple color was formed as the intensity of protein after added Biuret reagent and measure at $546 \mathrm{~nm}$ wavelength.

\section{Total Lipid (TL)}

The total lipids in two control groups and treated homogenate of $5^{\text {th }}$ instars larvae of $G$. mellonella were rated according to method of Zollner and Kirsch (1962). Lipids determined with sulfuric, phosphoric acids, and vanillin as color reagents reaction and estimated calorimetrically at $545 \mathrm{~nm}$.

\section{Acid phosphatase:}

The acid phosphatase activity was estimated using method of Powell and Smith (1954) as the amount of phenol product by enzymatic hydrolysis reaction with disodium phenyl phosphate as substrate.

$\alpha$-and $\beta$-estrases activities $\alpha$-and $\beta$-naphthol product resulted from of hydrolysis of $\alpha$-naphthyl acetate (strong blue) and $\beta$-naphthyl acetate (strong red as substrate, respectively), were calorimetrically measured at $510 \mathrm{~nm}$ (Van Asperen, 1962).

\section{Phenoloxidase (PO)}

Phenoloxidase activity was estimated according to the method of Ishaaya (1971) using catechol as the substrate. The reaction mixture consisted of $0.5 \mathrm{~mL}$ phosphate buffer $(0.1 \mathrm{M}, \mathrm{pH} 7), 200 \mu \mathrm{L}$ enzyme solution, and $200 \mu \mathrm{L}$ catechol solution (2\%). The activity was measured calorimetrically at $405 \mathrm{~nm}$.

\section{Statistical analysis}

The median lethal concentration, $\mathrm{LC}_{50}$ values were estimated using Biostat version 5 Analyst soft program with probit-analysis (Finney, 1971). The data obtained from biochemical studies were presented in mean and statistically analyzed using one-way (ANOVA), Turk- 
ey's HSD; with least significant difference at $p \leq 0.05$ by computer statistical software (Costat, 2005).

\section{RESULTS}

\section{Toxicological bioassay}

The toxicity of natural products extracted from $L$. sativum seeds as methanolic extract showed that the calculated median lethal concentration $\left(\mathrm{LC}_{50}\right)$ is $1.154 \%$ conc. (Table 1). This dose is in needed to kill $50 \%$ of $G$. mellonella $5^{\text {th }}$ instar larvae after 24 hours of dipping techniques with a slope of 0.638. The morphology of treated dead larvae was observed in Figure (1) as swollen, shrinkage, and softens black-brownish bodies that resulted from oxidation of cuticle comparable to the healthy one.

\section{Identification of bioactive chemical compounds of methanolic extract of Lepidium sativum seeds}

There are ten major compounds, of defatted seed methanolic extract of $L$. sativum, were detected by chromatogram of GC-MS (Figure 2). Data emphasized the presence of 2,3,4-Tri-methoxycinna-mic acid which equivalent to $20.44 \%$ of extract followed by Benzyl nitrile, also known as Benzyl cyanide (15.29\%), 5Hydroxy-methylfurfural (11.03\%), Benzene, (isothiocyanatomethyl)-(7.35\%), $\beta$-D-Gluco-pyranose, 1,6-anhydro-(5.63\%) and 11-Octadecenoic acid, methyl ester $(5.48 \%)$, respectively (Table 2). While, the minor compounds are Tetrafluoroanisole (3.40\%), Hexadecanoic acid, methyl ester (2.22\%), 2Furancarboxaldehyde, 5-methyl (1.75\%), and Furfural $(1.74 \%)$, respectively (Table 2$)$.

Table (1): Median lethal-dose effect of L. sativium methanolic extract on G. mellonella $5^{\text {th }}$ instar larvae.

\begin{tabular}{|c|c|c|c|c|c|}
\hline \multirow[t]{2}{*}{ Median Lethal concentration \% } & \multirow[t]{2}{*}{ Conc. $\%$} & \multicolumn{2}{|c|}{$\begin{array}{l}\text { Confidence } \\
\text { limits \% }\end{array}$} & \multirow[t]{2}{*}{ Slope } & \multirow{2}{*}{$\begin{array}{c}\text { Chi- } \\
\text { square }\end{array}$} \\
\hline & & lower & upper & & \\
\hline $\mathrm{Lc}_{50}$ & 1.154 & 0.569 & 2.232 & 0.638 & 0.0027 \\
\hline
\end{tabular}

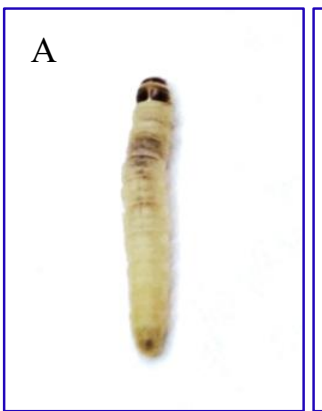

B
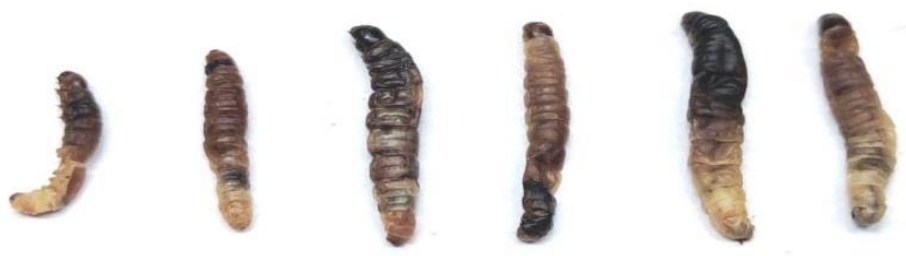

Figure(1): The comparison between (A): healthy one, creamy in colour whereas (B): Dead larvae, swollen, soften and blackbrownish till darken in colour after $24 \mathrm{~h}$ of dipping in $\mathrm{LC}_{50}$ of methanolic extract of $L$. sativum seeds.

The total area of identified bioactive compounds occupied $(74.33 \%)$ of L. sativum seed methanolic extract. Basically, the peak area, retention time, mass spectrum, and similarity percent of each compound in comparison with NIST library were taken into consideration in the identification of bioactive compounds.

\section{Histopathological studies}

The histological studies on the integument and muscles of the 5th larval instar of $G$. mellonella showed considerable structural changes after treatment with LC50, (1.15\%) of L. sativum methanolic seeds extract. The longitudinal section in normal integument

Table (2): The identified-GCMS phytochemical compounds of methanolic extract of Lepidium sativum seeds.

\begin{tabular}{lllllll}
\hline \hline Peak no & Rt & Compound name & Compound formula & Mwt & Area\% & CAS no. \\
\hline 1 & 2.28 & Furfural & $\mathrm{C}_{5} \mathrm{H}_{4} \mathrm{O}_{2}$ & 96 & 1.74 & $98-01-1$ \\
2 & 2.83 & 2-Furancarboxaldehyde, 5-methyl- & $\mathrm{C}_{6} \mathrm{H}_{6} \mathrm{O}_{2}$ & 110 & 1.75 & $620-02-0$ \\
3 & 4.04 & Benzyl nitrile & $\mathrm{C}_{8} \mathrm{H}_{7} \mathrm{~N}$ & 117 & 15.29 & $140-29-4$ \\
4 & 5.2 & 5-Hydroxymethylfurfural & $\mathrm{C}_{6} \mathrm{H}_{6} \mathrm{O}_{3}$ & 126 & 11.03 & $67-47-0$ \\
5 & 5.87 & Benzene, (isothiocyanatomethyl)- & $\mathrm{C}_{8} \mathrm{H}_{7} \mathrm{NS}_{7}$ & 149 & 7.35 & $622-78-6$ \\
6 & 8.48 & 2,3,5,6-Tetrafluoroanisole & $\mathrm{C}_{7} \mathrm{H}_{4} \mathrm{~F}_{4} \mathrm{O}$ & 180 & 3.4 & $2324-98-3$ \\
7 & 9.63 & 3-D-Glucopyranose, 1,6-anhydro- & $\mathrm{C}_{6} \mathrm{H}_{10} \mathrm{O}_{5}$ & 162 & 5.63 & $498-07-7$ \\
8 & 15.75 & -Hexadecanoic acid, methyl ester & $\mathrm{C}_{17} \mathrm{H}_{34} \mathrm{O}_{2}$ & 270 & 2.22 & $112-39-0$ \\
9 & 21.78 & 11-Octadecenoic acid, methyl ester & $\mathrm{C}_{19} \mathrm{H}_{36} \mathrm{O}_{2}$ & 296 & 5.48 & $52380-33-3$ \\
10 & 24.98 & $2,3,4-$-Trimethoxycinnamic acid & $\mathrm{C}_{12} \mathrm{H}_{14} \mathrm{O}_{5}$ & 238 & 20.44 & $33130-03-9$ \\
\hline \hline
\end{tabular}




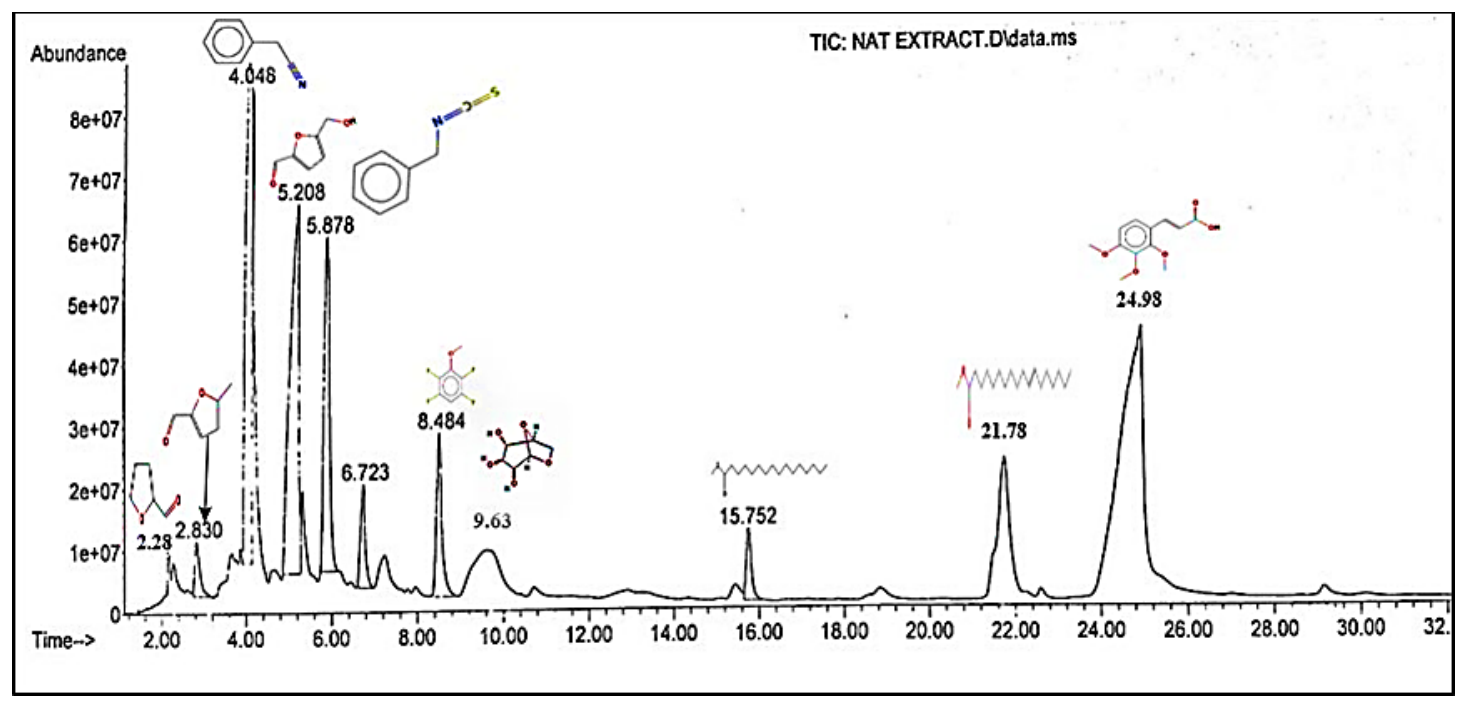

Figure (2): GC-MS Chromatogram of Lepidium sativum defatted seed methanolic extract.

showed that it is typically formed of a single layer of epidermal cells and a non-cellular cuticle secreted by these cells. The epicuticular tubercle was noticed in the control group. The procuticle is composed of chitin fibrils with pore channels in the lamellar structure parallel to each other. Epicuticle, exocuticle, and endocuticle, are in turn, the endocuticle lamella as a result of chitin synthesis by epidermal cells.

Multilocular adipose tissue (fat body) was observed tightly clustered in closed to the integument (Figure 3A $\& B)$. After treatment the layer of the epidermal cells became disorganized and completely dispersed under the deformed integument. Furthermore, the appearance of large vacuoles and dimension of fat body (Figure 3C\&E), deformity of procuticle chitin fibrils, absence of epicuticular tubercle, complete separation of epidermal cell and vacuolation in the fat body were also observed in (Figure 3E). Generally, in treated larvae the cuticle did not display a lamellar appearance (Figure 3C, D, E\&F). The control longitudinal muscles are composed of striated fibers. Each fiber consists of several paralleled fibrillate or sacrostyles, in circular muscle sacrostyles occupying the whole of the crosssection of the fiber and are laid down in plasma or sacroplasm.

The nuclei of the sacroplasm are disposed immediately beneath the sarcolemma (Figure 3B). Malformation of muscles of treated larvae undergoes progressive structural damage ranged from slight degeneration by the occurrence of fissures, to the destruction of the whole tissues which are attributed to the destruction of the sarcolemma (Figure 3D\&F).

\section{Influence of of methanolic extract of Lepidium sativum seeds on DNA fragmentation}

DNA fragmentation into oligonucleosomal size fragments is a remarkable and characteristic feature that indicates the damage of DNA and considered as an integral part of apoptosis of cells. The influence of tested methanolic extract of L. sativum seeds on genomic DNA of 5th larval instar of G. mellona at 3, 2, and $1 \%$ (LC50) concentrations were observed and estimated by measuring the level of genomic DNA fragmentation through detecting DNA laddering on agarose gel electrophoresis (Fig. 4). The data obtained, compared to the control groups (negative and positive control, respectively) after $24 \mathrm{~h}$ after treatments, showed smeared fragmented DNA.

Data retrieved from the gel analyzing image, principally, indicated that the individuals of $5^{\text {th }}$ instar larva treated with the methanolic extract, in a dosedependent manner, displayed an induce marked DNA fragmentation at variable levels with a smear pattern of DNA fragmentation. This confirmed when compared with the used DNA ladder where both high molecular weight DNA and smaller DNA fragments were reported (Fig. 5). Additionally, the control groups (distilled water and methanol, respectively) showed sharp clear bands of intact DNA.

\section{Biochemical assay}

Result in table (3) expressed the treatment of defatted methanolic seed extract of $L$. sativum which revealed a highly significant reduction in total soluble protein and the activities of different enzymes studied, $\alpha$ and $\beta$ esterase, and phenoloxidase activities.

Meanwhile, the total lipid content recorded high significant elevation $(262.37 \mathrm{mg} / \mathrm{ml}$ and $227.98 \mathrm{mg} / \mathrm{ml}$ for treated and control groups, respectively). In parallel, acid phosphatase activity recorded the same behavior pattern and recorded a high significant elevation $(p \leq 0.05)$ in comparison to controlled groups $(6.87 \mu \mathrm{g} / \mathrm{g} / \mathrm{min}$ and $1.73 \mu \mathrm{g} / \mathrm{g} / \mathrm{min}$ for treated and control groups, respectively).

\section{DISCUSSION}

The beekeeping industry with high economic importance is suffering from a serious apiary pest known as a greater wax moth, G. Mellonela. Controlling such harmful pests with conventional chemical pesticides comprising difficulty summarized. 

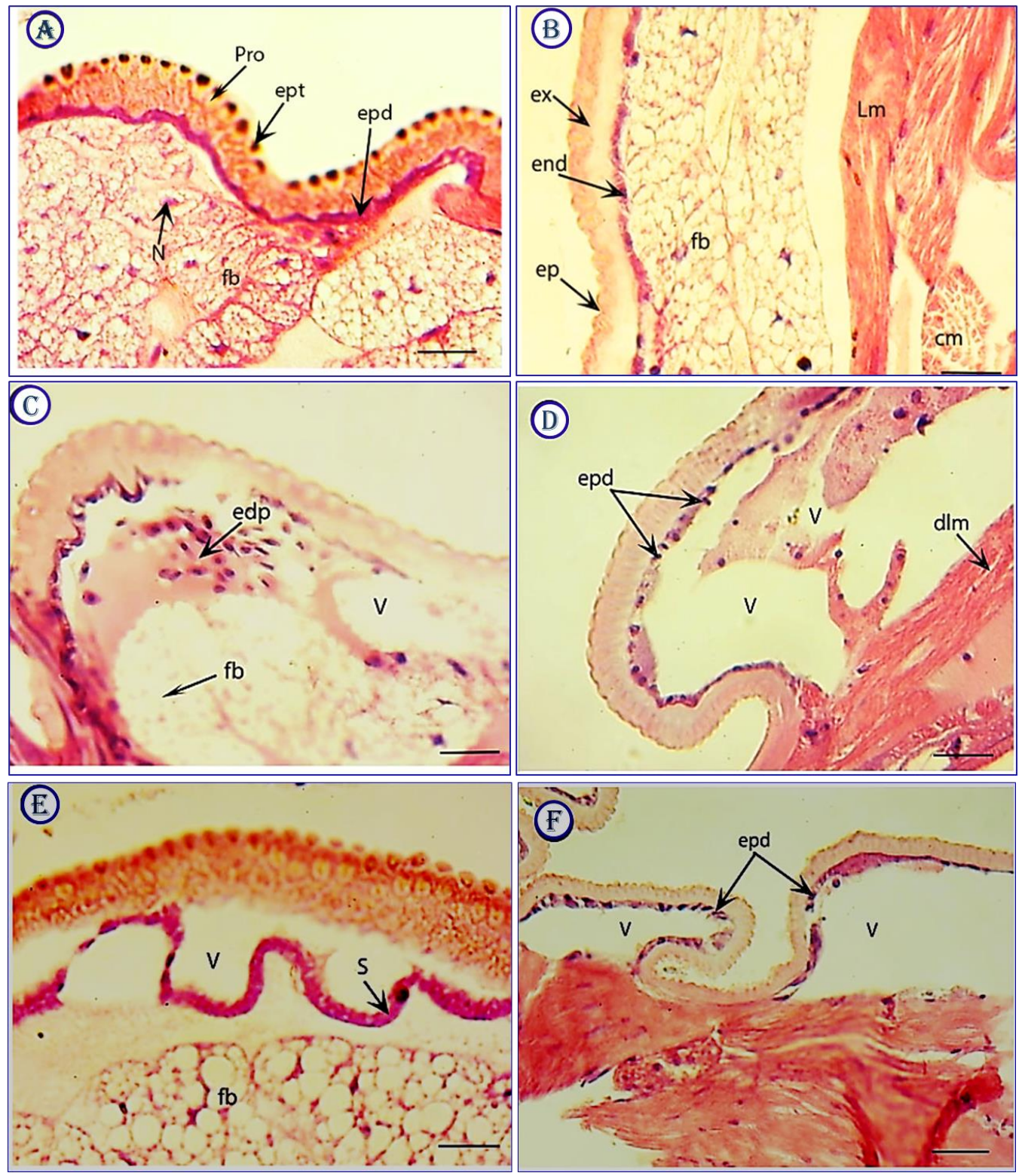

Figure (3): L.S of the cuticular layer in the fifth instar G.mellonella larvae treated with methanolic extract of $L$. sativum seeds verses to control groups. A and B, showing normal structure of the cuticular layer of control group in which procuticle (pro), epicuticle (ept) and epidermal cell (epd) showed normal structural pattern; B, showed exocuticle, (ex), endocuticle (end), epidermal cell (epd), longitudinal muscle (Lm), circular muscle ( $\mathrm{cm}$ ) and fat body (fb); C, D, E and F, represented treated groups of G.mellonella larvae in which deformed structure of cuticle layers, rapture of epidermal cell, vacuolated (v) and deformed fat bodies and deformed longitudinal muscles (dlm)

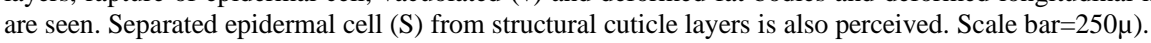




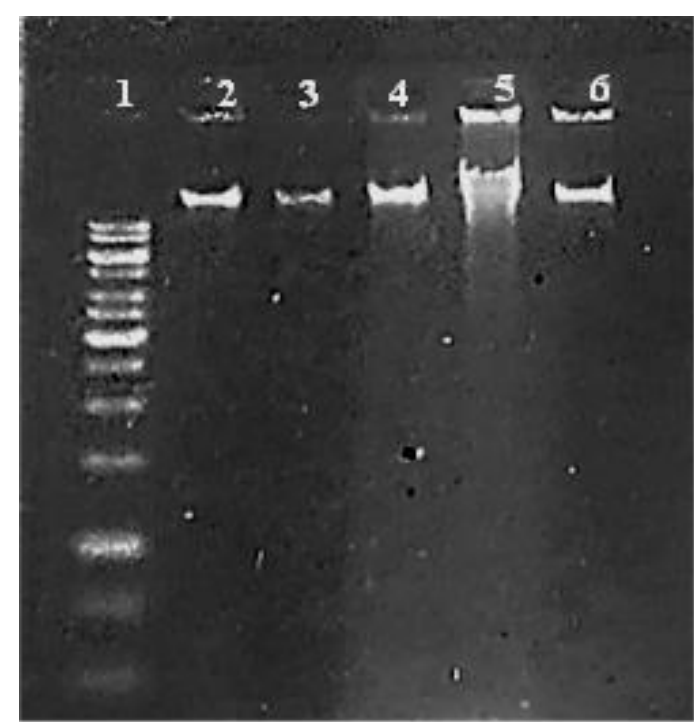

Figure (4): Gel image of DNA of $5^{\text {th }}$ instar larvae of $G$. mellonella, $\mathrm{L}$ showing different experimental groups; Lane (1), DNA standard ladder (10000 bp); Lanes2 and 6,: Negative and positive control groups $\left(\mathrm{d} . \mathrm{H}_{2} \mathrm{O}\right.$ and methanol extract, respectively) of DNA of $5^{\text {th }}$ instar larvae of $G$ mellonella; Lanes 3-5, DNA of the $5^{\text {th }}$ instar larvae treated with $3 \%, 2 \%, 1 \%\left(\mathrm{LC}_{50}\right)$, of methanolic extract of L. sativum, respectively. in to reduce the quantity of the produced honey besides, the negative effect on the environment and human health. Finding out new alternatives based onsafe bioactive compounds from natural plant extract represents a recommenced choice. GC-Ms analysis of defatted seeds methanolic extract of $L$. sativum, exhibited the major compounds were $(2,3$, 4, Trimethoxycinnamic Benzyl nitrile), (5-Hydroxymethylfurfural), (Benzene-(isothiocyanatomethyl), ( $\beta$-D-Glucopyranose-1,6-anhydro-) and (11-Octadecenoic acid, methyl ester), respectively. On the other hand, the minor were (2,3,5,6-Tetra-fluoroanisole), (-Hexadecanoic acid- methyl ester), (2-Furancarboxaldehyde-5-methyl), and Furfural, respectively. These Identifications were approved by Hussein et al., (2017) who identified 2 compounds of furfural derivatives are 2-Fura-ncarboxaldehyde-5-methyl and 5-Hydroxym-ethylfurfural compounds in the methanolic extract of L. sativum seed. Also, 11octadecenoic acid and hexadecadienoic acid were the major constituents of hydrodistillation seeds oil (Alqahtani et al., 2019). Benzyl nitrile and Benzene, (isothiocy-anatomethyl) with area percentages $15.29 \%$ and $7.35 \%$, respectively, were identified.

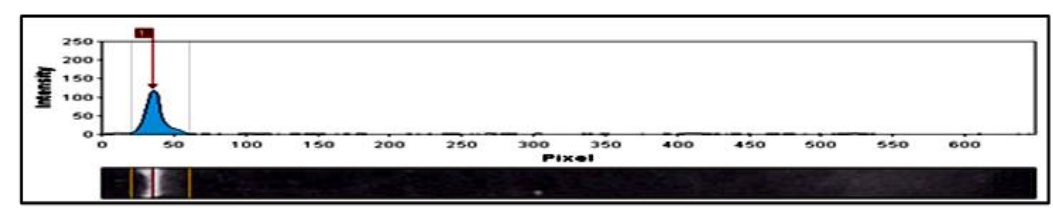

Lane(2): Control

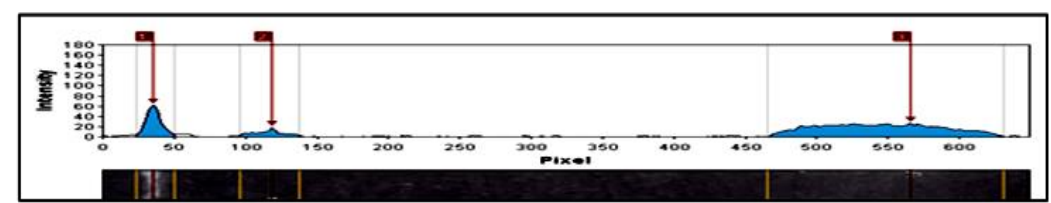

Lane(3): $3 \%$ concentration

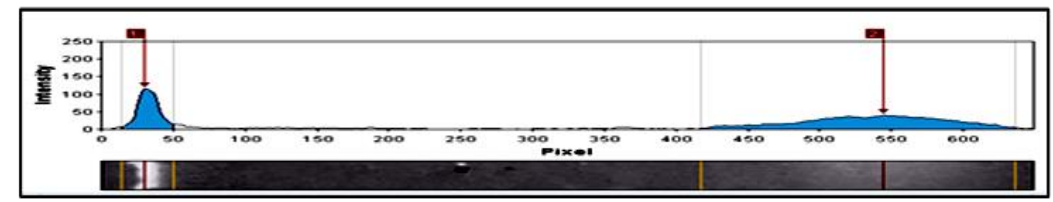

Lane(4): $2 \%$

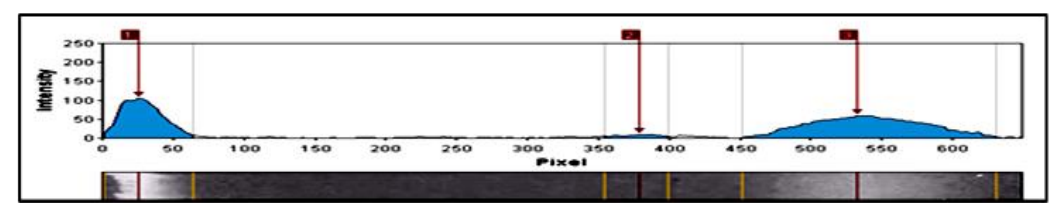

Lane(5):1\% concentration

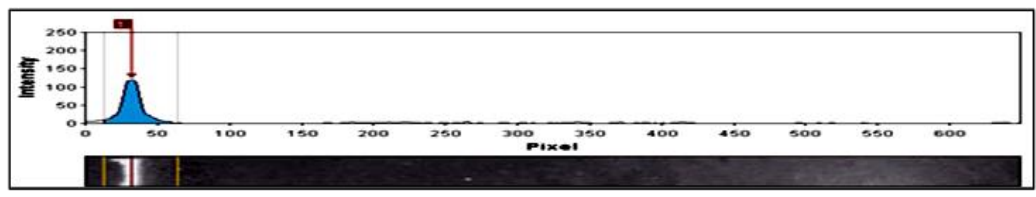

Lane(6): Control

Figure (5): Gel electrophoresis image analyses of DNA fragmentation for $5^{\text {th }}$ instar larvae of G. mellonella after $24 \mathrm{~h}$ of treatment with methanolic extract of $L$. sativum seeds. 
Table (3): The biochemical response of $5^{\text {th }}$ larval instar of $G$. mellonella treated with LC50 of L. sativum seed extract after $24 \mathrm{~h}$.

\begin{tabular}{|c|c|c|c|c|c|c|}
\hline Treatments & $\operatorname{TSP}^{\dagger}(\mathbf{m g} / \mathbf{g})$ & $\begin{array}{c}\mathbf{T} \mathbf{L}^{\dagger \dagger} \\
(\mathrm{mg} / \mathrm{ml})\end{array}$ & ACP $\mu \mathrm{g}$ phenol /g/min & $\begin{array}{c}\alpha \text { esterase }(\mu \mathrm{g} \\
\alpha-\text { naphthol } \\
/ \mathrm{g} / \mathrm{min})\end{array}$ & $\begin{array}{l}\beta \text { esterase ( } \mu \mathrm{g} \text { - } \\
\text { naphthol /g/min) }\end{array}$ & $\begin{array}{c}\text { Phenol } \\
\text { oxidaseU/g }\end{array}$ \\
\hline Control & $80.5^{\mathrm{a}}$ & $227.98^{b}$ & $1.73^{\mathrm{b}}$ & $0.31^{\mathrm{a}}$ & $7.91^{\mathrm{a}}$ & $173.76^{\mathrm{a}}$ \\
\hline L. sativum & $32.08^{b}$ & $262.37^{\mathrm{a}}$ & $6.87^{\mathrm{a}}$ & $0.11^{\mathrm{b}}$ & $4.14^{\mathrm{b}}$ & $133.71^{\mathrm{b}}$ \\
\hline LSD & 3.64 & 9.08 & 3 & 0.02 & 1.08 & 33.15 \\
\hline$P^{*}$ & $0.0000^{* * * *}$ & $0.0005^{* * *}$ & $0.009^{* *}$ & $0.0000^{* * *}$ & $0.0007^{* * *}$ & $0.025^{*}$ \\
\hline
\end{tabular}

${ }^{*}$ The result revealed significance at $p<0.05$; LSD, Least significance difference; different letter for each column showed significant differences; $\left({ }^{* * *}\right)$, highly significance; $\left(^{* *}\right)$, moderate significance; $\left(^{*}\right)$, low significance ${ }^{\dagger} \mathrm{TSP}$, Total Soluble Protein; ${ }^{\dagger \dagger} \mathrm{TL}$, Total Lipids.

Similar observation revealed that Benzyl nitrile $(16.23 \%)$ and Benzene, isothiocyana-tomethyl $3.89 \%$ (Malar et al., 2018), the isothiocy-anates compound as most influential component present in garden cress seed (Kassie et al., 2002).

The toxicological experimental data clarified that $L$. sativum extract has a toxic effect on the $5^{\text {th }}$ larvae of $G$. mellonella with $\operatorname{LC}_{50}(1.15 \%)$, as a consequence of integument swelling and melanization of cuticle larvae and darkening colour till deaths. The cuticle darkening color of insect hemolymph or melanization resulted from phenoloxidase enzyme activity is an important feature that indicates the insect infection with toxins, microbial microorganisms, and abiotic stressors (Whitten and Coates 2017). The presence of furfural and its derivatives as well, which used as fungicides, nematicides and insecticides in a safe and easy agrochemical application. These results are in harmony with those of Kumar and Yadav (2018) who demonstrated the insecticidal activity of Abrus precatorius, Laurus nobilis, Petroselinum sativum, and Plantago psyllium extracts with mortality percent ranged between (95-100\%).

G. mellonella larvae are supporting with integument contain a chitinous substance. The integument forms a composite structure named the cuticle which forms the skeleton of the insect body its origin is the ectoderm covers the internal organs like the trachea, the fore, and hindgut which play a vital role as a first insect defense mechanism (Wojda, 2017). The treatment after 24h with $\mathrm{LC}_{50}, 1.15 \%$ of methanolic extract of L. sativum destructed the integument, epidermal layer; muscle, and fat bodies of larvae. The occurrence of integument disturbance is dependent on the promotion of protein degradation in the outermost layers of insect covering of the whole insect body. The acute toxicity of garden cress methanolic extract as destructive in cuticle layer and fat bodies is possibly related to a combination of phytochemical active compounds as Benzene-(isothiocyanatomethyl)-, $\beta$-D-Glucopyranose- 1-6-anhydro- , 2,3,4-Trimethoxycinnamic acid, 11-Octadecenoic acid methyl ester and Hexadecanoic acid methyl ester. The damage in the cuticle layers due to such compounds induced the insect defense mechanisms through the signalling pathways which regulate the expression of antimicrobial peptides to be liberated in hemolymph
(Wojda et al., 2020). Because of the non-sclerotized cuticle of $G$. mollenella larvae which leads to ease the penetration of the seeds extract in the body and accelerates the death. The treated larvae observed large vacuoles and dimensions of the fat bodies also, deformity in procuticle chitin fibrils, absence of epicuticular tubercle, and complete separation of epidermal cell these vacuoles are formed as a consequence of intoxication these results are supported by Perdoni et al., (2014). Fat bodies transport hydrocarbons such as n-pentacosane 3-methyl pentacosane and 6, 9heptacosadiene that are used in the formation of the cuticle from the site of their production in the oenocytes of the fat bodies. The insect fat body implicated in insect metamorphosis and development (Liu et al., 2009).

L. sativum methanolic extract of defatted seeds caused damage in DNA of G. mellonella $5^{\text {th }}$ instar larvae in all tested concentrations with a variation intensity after $24 \mathrm{~h}$ post-treatment. Earlier studies proved that garden cress extracted and their bioactive chemical compounds stimulate apoptosis in cells (Diwakara et al., 2008). Alkaloids constitute (benzylisothiocyanate) induce DNA fragmentation after 96h in the human breast cancer cell (Karazhiyan et al., 2009).

The biochemical responses of $5^{\text {th }}$ instar larvae of $G$. mellonella to the $\operatorname{LC}_{50}(1.15 \%)$ of $L$. sativum methanolic extract seed were observed. The protein level, $\alpha \& \beta$ esterase and phenol oxidase activities showed a highly significant reduction on the contrary the total lipid content and acid phosphatase activity exhibited high elevation. The protein content is vital in all biological processes for $G$. mellonella larval development. Data revealed the amount of total soluble protein content is $(32.08 \mathrm{mg} / \mathrm{g})$ in treated larvae while reached to $80.5 \mathrm{mg} / \mathrm{g}$ in untreated ones. The reduction of protein level may affect protein synthesis responsible for spinning silk which is protective tubes, used in larval feeding at the cocoon stage as a result of the deficiency of essential amino acids needed (Shaik et al., 2017). Moreover, the explanation of protein deficiency perhaps might be attributed to 1) the utilization of protein in detoxification enzyme activity to eliminate the insecticidal action of L. sativum seed methanolic extract and 2) suppression of the synthesis of DNA and RNA (El-barky et al., 2008). In addition 
to, Esterases ( $\alpha-$ EST and $\beta$-EST) which are considered pivotal detoxifying enzyme which hydrolyses the esteric bond in toxic chemicals, they have been reported to possess detoxification ability against synthetic and botanical insecticides (Zibaee and Stoytcheva 2011).

In this study, L. sativum seeds methanolic extract causes significant elevation of lipid in the $5^{\text {th }}$ instar larvae of the $G$. mellonella $(262.37 \mathrm{mg} / \mathrm{g})$. The high lipid content in $G$. mellonella results in retention of the lipophilic compound in the fat layer. The lipophilicity increases as alkyl chain length increase due to poor distribution of increasing lipophilic ionic liquids. This leads to localization of injected ionic liquids to support melanization as a result of the stress of infection and leads to the larvae changing from cream-colored to dark brown or black (Kavanagh and Fallon, 2010). The activities of acid phosphatase, esterases, and phenoloxidase as detoxification enzymes involved indirectly in the formation of insect resistance mechanisms, the cress seed extract caused a highly significant increase in acid phosphatase. On the other hand, the activities of esterases and phenoloxidase were frustrated.

Phenoloxidases are manipulating insect development and immunity for the early immune defense in convert pigment (quinones) into melanin. Reduction of phenoloxidase enzymes in larvae treated with seed methanolic extract might prevent the hardened process of the cuticle and stop its function to protect the soft entire organs pest that lead to weaken the immune system (Hiromori and Nishigaki, 2001).

\section{CONCLUSION}

This study demonstrated high biological activity of the methanolic extract of $L$. sativum defatted seeds on $5^{\text {th }}$ instar larvae of greater wax moth, G. mellonella. The high toxicological impact and biochemical alterations of such extract could offer great opportunity and seems a promising alternative low cost tactics for controlling $G$. mellonella. Furthermore, the biological activity of the methanol extract has been confirmed due to the enrichment of active phytochemical components that stimulate insect cell damage on genome level and integument histology. These findings make that the $L$. sativum methanol seeds extract can be used in the IPM program in controlling greater wax moth.

\section{REFERENCES}

ALQAHTANI, F. Y., F. S. ALEANIZY, A. Z. MAHMOUD, N. N. FARSHORI, R. ALFARAJ, E.S. AL-SHEDDI, AND I.A. ALSARRA. 2019. Chemical composition and antimicrobial, antioxidant, and anti-inflammatory activities of Lepidium sativum seed oil. Saudi journal of biological sciences, 26(5): 1089-1092.

BASAIYYE, S.S., S. KASHYAP, K. KRISHNAMURTHI, AND S. SIVANESAN. 2019. Induction of apoptosis in leukemic cells by the alkaloid extract of garden cress (Lepidium sativum L.). Journal of integrative medicine, 17(3): 221-228.

BORTNER, C.D., N.B. OLDENBURG AND J.A. CIDLOWSKI. 1995. The role of DNA fragmentation in apoptosis. Trends Cell Biology, 5:21-26.

CHATOUI, K., A. TALBAOUI, M. ANEB, Y. BAKRI, H. HARHAR AND M. TABYAOUI. 2016. Phytochemical screening, antioxidant and antibacterial activity of Lepidium sativum seeds from Morocco. J. Mater. Environ. Sci. 7(8): 29382946.

COSTAT STATISTICAL SOFTWARE, 2005. Microcomputer program analysis version, 6.311. Co Hort Software, Monterey, California, USA.

DIWAKARA, B.T., P.K. DUTTAA, B.R. LOKESHB, AND K.A. NAIDU. 2008. Bioavailability and metabolism of n-3 fatty acid rich garden cress (Lepidium sativum) seed oil in albino rats. Prostaglandins, Leukotrienes and Essential Fatty Acids 78: 123-130.

EL-BARKY, N. M., H. F. DAHI, AND Y. A. ELSAYED. 2008. Toxicological evaluation and biochemical impacts for radient as a new generation of spinosyn of Spodoptera littoralis (Boisd.), larvae. Egypt. Acad. J. Biol. Sci., 1(2): 85-97.

El-Gendy, R. M. AND S.N. El-Shafiey. 2018. EcoFriendly Control Strategies of Green Stink Bug, Nezara viridula L. (Hemiptera: Pentatomidae): Repellency and Toxicity Effects of Callistemon citrinus, Bottle Brush Essential Oil. J. Plant Prot. and Path., Mansoura Univ., 9 (12): 807 - 813.

ELLIS, J.D., J.R. GRAHAM, AND A. MORTENSEN. 2013. Standard methods for wax moth research. J. Apic. Res., 52: 1-17.

FATHY, D.M., H.M. FATHY, H.M. MANSOUR, AND M. A. ZEIDAN. 2017. Activity of the greater wax moth Galleria mellonella L. and the lesser wax moth Achroia grisella F. in Apiary and Storage in Kafr El-Sheikh Province. J. Plant Prot. and Path., Mansoura Univ., 8 (10): 497-500

FINNEY, D.J. 1971. Probit analysis. $3^{\text {rd }}$ Edition, Cambridge University London, Cambridge, 333.

GORNALL, J.G., G.J. BARDWILL, AND M.M. DAVID. 1949. Determination of serum protein by mean of biuret reaction. J. Bio. Chem., 117: 751766.

HIROMORI, H. AND J. NISHIGAKI. 2001. Factor analysis of synergistic effect between the entomopathogenic fungus Metarhizium anisopliae and synthetic insecticides. Appl. Entomol. Zool. 36: 231- 236.

HOSAMANI, V., B.C.H. SWAMY, K.N. KATTIMANI AND C.M. KALIBAVI. 2017. Studies on Biology of Greater Wax Moth (Galleria mellonella L). Int. J.Curr. Microbiol.Appl. Sci. 6 (11): 38113815 .

HUSSEIN, H.M., I.H. HAMEED, AND O.A. IBRAHEEM. 2017. Antimicrobial Activity and spectral chemical analysis of methanolic leaves extract of Adiantum Capillus Veneris using GC-MS and FT-IR spectroscopy', Inter. J. of Pharm- 
acognosy and Phytochemical Research, 8 (3): 369385.

HUSSIEN, R. H., S. M EZZAT, A. A. EL SHEIKH, J. W. TAYLOR, AND T.M. BUTT, 2021. Comparative study of fungal stability between Metarhizium strains after successive subculture. Egyptian Journal of Biological Pest Control, 31(1), 1-6.

ISHAAYA, I. 1971. Observation on the phenoloxidase system in the armored scales Aonidiella auranti and chrysomphalus aonidum. Comp. Biochem.physiol., 39:935 - 943 .

KARAZHIYAN, H., S.M.A. RAZAVI, G.O. PHILLIPS, Y. FANG, S. AL-ASSAF, K. NISHINARI, AND K. R. FARHOOSH. 2009. Rheological properties of Lepidium sativum seed extract as a function of concentration, temper-ature and time. Food Hydrocolloids 23: 2062-2068.

KASSIE, F., S. RABOT, M. UHL, W. HUBER, H. QIN, M., HELMA, AND S., KNASMÜLLER. 2002. Chemo-protective effects of garden cress (Lepidium sativum) and its constituents towards 2amino-3-methyl-imidazo [4, 5-f] quinoline (IQ)induced genotoxic effects and colonic preneoplastic lesions. Carcinogenesis, 23(7):1116-1155.

Kavanagh, K., AND J.P. Fallon. 2010. Galleria mellonella larvae as models for studying fungal virulence. Fungal Biology Reviews, 24 (1-2), 79-83

KOUL, O., S. WALIA, AND G. S. DHALIWAL, 2008. Essential oils as green pesticides potential and constraints. Biopestic. Int. 4 (1): $63-84$.

KUMAR, L. Y. AND S. YADAV. 2018. Effectiveness of different plant extracts against Galleria mellonella larvae in laboratory. Archives of Agriculture and Environmental Science, 3 (1): 6467.

LAZAR, I., 2010. Gel Analyzer. Freeware 1D gel electrophoresis image analysis software: http://www. Gel-analyzer. Com.

LIU, Y., H. LIU, S. LIU, S. WANG, R.J. JIANG AND S. LI. 2009. Hormonal and nutritional regulation of insect fat body development and function. Archives of Insect Biochemistry and Physiology: Published in Collaboration with the Entomological Society of America, 71(1): 16-30

MALAR, M. J. S., J.S. VANMATHI, AND K. CHAIRMAN. 2018. Phytochemical analysis of Lepidium sativum using UV-VIS and GC-MS. Int. J. Adv. Res. 6(9): 813-825.

MOHAMED, A., M. J. ANSARI, A. AL-GHAMDI, M.O. MOHAMED AND M. KAUR. 2014. Effect of larval nutrition on the development and mortality of Galleria mellonella (Lepidoptera: Pyralidae).
Rev-ista Colombiana de Entomología (40): 49-54.

OWAYSS, A.A. AND A.A. ABD-ELGAYED. 2007.

Potential Efficacy of Certain Plant Volatile Oils and Chemicals against Greater Wax Moth, Galleria

mellonella L. (Lepidoptera: Pyralidae). Bull. Ent. Soc. Egypt, Econ. Ser., (33): 67-75.

PERDONI, F., M. FALLENI, D. TOSI, D. CIRASOLA, S. ROMAGNOLI, P. BRAIDOTTI, AND E. BORGHI. 2014. A histological procedure to study fungal infection in the wax moth Galleria mellonella. Eur J. of histo-chemistry: EJH, 58(3).

Phillips, A.J. AND C. Simon. 1995. Simple, Efficient, and Nondestructive DNA Extraction Protocol for Arthropods. Annals of the Entomological Society of America, 88(3): 281-283.

Powell, M. E. A. AND M. J. H. Smith. 1954. The determination of serum acid and alkaline phosphatase activity with 4-aminoantipyrine. J. Clin. Pathol., 7: 245-248.

Shaik, H.A., A. Mishra, AND F. Sehnal. 2017. Silk recycling in larvae of the wax moth, Galleria mellonella (Lepidoptera: Pyralidae). Eur J Entomol. 114: 61-65.

Shail, M.D., K. Neeraj, AND L.N. Gupta. 2016. Nutritional importance of Lepidium sativum L. (Garden cress/ Chandrashoor): A review. Int J Pharm Anal Res. 5(1):152-160.

Wojda I. 2017. Immunity of the greater wax moth Galleria mellonella. Ins Sci. 24: 342-357.

Wojda, I., M. Cytryńska, A. Zdybicka-Barabas AND J. Kordaczuk. 2020. Insect defence proteins and peptides. Subcell Biochem 94:81-121.

Whitten, M. AND C.J. Coates. 2017. Re-evaluation of insect melanogenesis research: views from the dark side. Pigment Cell Melanoma Res. 30(4): 386-401.

Van Asperen, K. 1962. A study of housefly esterases by means of a sensitive colorimetric method. J. of insect physiology, 8(4): 401-416.

YADAV, Y.C. D.N. SRIVASTAV, A.K. SETH, V. SAINI, R. BALARAMAN, AND T.K. GHELANI. 2010. In vivo antioxidant potential of Lepidium sativum seeds in albino rats using cisplatin induced nephrotoxicity, Int. J. Phytomed. 2: 292-298.

ZIBAEE, A., \& STOYTCHEVA, M. 2011. Botanical insecticides and their effects on insect biochemistry and immunity. In:M. Stoytcheva (Ed.), Pesticides in the Modern World-Pests Control and Pesticides Exposure and Toxicity Assessment, (pp. 55-68). InTech, Open Access Publisher, USA.

ZOLLNER, N., AND K. KIRSCH, 1962. Micro determ- ination of lipids by the sulphophosphovanillin reac- tion. Z. Ges. Exp. Med, 135:545-5. 


\title{
التأثيرات السمية والهيستولوجية والكيميائية الحيوية لمستخلص بذور حب الرشاد في مكافحه دودة الثمع Galleria mellonella الكبري
}

\author{
ريحاب محمود الجندي \\ قسم بحوث فسيولوجيا الافات، معهد بحوث وقايه النباتات، مركز البحوث الزراعيه، دقي، جيزة، مصر \\ الملخص العربـــي
}

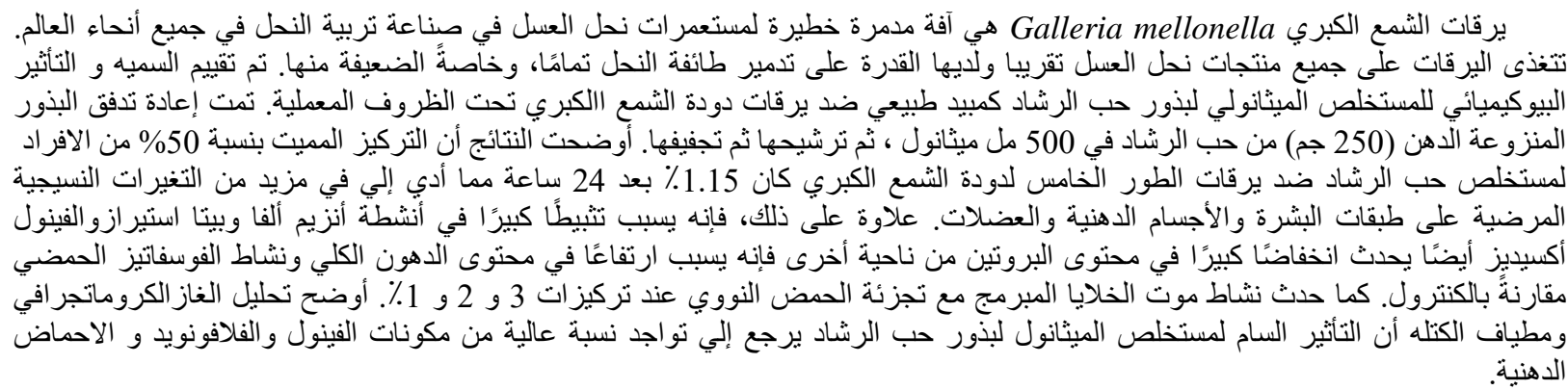

